\title{
ЗАМЕТКИ ОБ ЭТНИЧЕСКОМ ОБЛИКЕ СРЕДНЕВЕКОВОЙ ДУНАЙСКОЙ БОЛГАРИИ (XII-XIV ВВ.) ПО ДАННЫМ АРХЕОЛОГИИ И АНТРОПОЛОГИИ
}

\section{(C) 2021 г. Г. В. Владимиров}

В статье представлена динамика изменений этнического и культурного облика средневековых болгарских земель в XI-XIV веках, особое внимание уделено роли поздних кочевников в данных процессах. Кратко рассмотрены известные археологические следы новоприбывших этнических групп, заселивших эти земли в указанный хронологический период. Уделено внимание некоторым малоизвестным антропологическим данным, которые проливают дополнительный свет на исследуемые миграционные волны. Закономерно следует вывод о необходимости комплексного подхода к изучению зрелого и позднего болгарского средневековья с привлечением и интерпретацией максимального количества научных свидетельств исторического, археологического и антропологического происхождения.

Ключевые слова: археология, антропология, болгарские земли, поздние кочевники, печенеги, торки, куманы, аланы, татары, Византия, Второе болгарское царство

\section{NOTES ON THE ETHNIC APPEARANCE OF MEDIEVAL DANUBE BULGARIA $\left(12^{\mathrm{TH}}-14^{\mathrm{TH}}\right.$ CENTURIES) ACCORDING TO ARCHEOLOGICAL AND ANTHROPOLOGICAL DATA}

\section{G. Vladimirov}

The paper describes the dynamics of the ethnic and cultural situation in Bolgar lands in $12^{\text {th }}-4^{\text {th }}$ century with an emphasis on the late nomads' role in the processes. Known archaeological traces of newly arrived ethnic groups which settled in these lands in the reviewed chronological period are summarized in the paper. Attention is drawn to certain scarcely known anthropological data which additionally shed light on these migration waves. A conclusion was rightfully drawn on the necessity of complex approach in the study of the late Bolgar Middle Ages through attraction and interpretation of the maximum amount of scientific evidence of historical, archaeological and anthropological origin.

Keywords: archaeology, anthropology, late nomads, Bolgar lands, the Pechenegs, the Torks, the Cumans, the Alans, the Tatars, Byzantium, Second Bolgar Kingdom.

Данный текст ставит перед собой задачу представить в резюмированном виде известные эмпирические следы присутствия новых этнических групп, заселивших болгарские земли в первой половине II тысячелетия н. э. Без претензий на особую эвристичность его цель - возобновить дискуссию на тему восточных этнических и, соответственно, культурных влияний на средневековую болгарскую ойкумену.

Тема присутствия поздних кочевников на болгарских землях в период XI-XIV веков, благодаря письменным источникам, относительно хорошо описана в болгарской медиевистике. Именно поэтому мы лишь маркируем некоторые факты, определяющие рамку исследования, а больше внимания уделим археологическому и столь часто пренебрегаемому антропологическому аспекту данной проблемы.
Вначале необходимо отметить, что формирование этнокультурного облика средневековых болгарских земель - это длительный и последовательный процесс. После создания Дунайской Болгарии в конце VII века контакты с болгарскими группами региона Северного Причерноморья не были прекращены. Существуют археологические данные, говорящие о новых волнах переселенцев на Нижний Дунай в VIII-IX вв., которые привнесли «свежую кровь» в культуру Болгарии хана Аспаруха (Димитров, 1987).

Приток новых поселенцев стал более ощутим в эпоху византийского владычества. Развитие диаспоры стимулировали различные факторы, среди которых наиболее существенными были: нашествия поздних кочевников (печенегов, торков, куман), которые увлекали за собой и другие этносы, в том числе часть населения - носителя позднего вариан- 
та салтово-маяцкой культуры (болгар и алан). Связи Балкан с Востоком оставались активными и в XIII-XIV веках, при этом этническая картина Нижнего Дуная пополнилась новыми миграционными волнами. Таким образом, в глобальном масштабе этноним «болгарин» в балканской средневековой среде со временем претерпел метаморфозу и в эпоху Второго Болгарского царства постепенно приобрел значение политонима.

Приведенные выше утверждения могут быть эмпирически верифицированы археологическим и антропологическим путем. Однако это непростая задача по двум причинам. Первая - причина объективного характера, и связана она с быстрой восприимчивостью местных обычаев и традиций новыми этносами-переселенцами и в результате этого - стремительное стирание культурных границ между местным и вновь прибывшим населением. Вторая - причина, детерминированная традиционным субъективно-архаичным исследовательским подходом, который продолжает интерпретировать факты однозначно, лабораторно, без учета общего контекста, формируемого разнообразными информационными источниками (письменными и материальными). Именно об этом пойдет речь при рассмотрении антропологических данных о населении болгарских земель в интересующий нас хронологический период.

История позднекочевнических нападений на болгарские земли хорошо изучена, поэтому мы не будем на ней останавливаться (Тъпкова-Заимова, 1976; Атанасов, 1991; Гюзелев, 1995; Павлов, 2000; Стоянов, 2005). Первые миграционные волны поздних номадов - печенегов-переселенцев на Балканы, исходя из письменных свидетельств, датируются 30-40-ми годами XI века. Согласно византийским источникам, именно тогда сотни тысяч мужчин, женщин и детей прибывают на земли южнее Дуная, заселяя и создавая поселения в Северо-Восточной Болгарии, главным образом около старой болгарской столицы Плиски, а также на западе: на окраинах городов София, Ниш в Сербии и ОвчеПоле в Македонии. Постепенно пришельцы меняют свой образ жизни, отказываются от кочевого скотоводства и сезонной миграции. Некоторые исследователи придерживаются мнения, что современная этнографическая группа «шопы» в Западной Болгарии - это не кто иные, как потомки восточных номадов.

В 60-х годах XI века Балканы подвергаются вторжению торков. Тогда новые кочевники смогли проникнуть на территорию Северной Болгарии и достигли окраин города Салоники. Однако вскоре разразилась эпидемия, и византийской армии удалось отбросить непрошенных гостей, вернув их обратно на земли к северу от Дуная.

Во второй половине XI века на нынешних болгарских землях появляются куманы. В отличие от печенегов они переправлялись на юг от Дуная только в сезон свежей травы - с ноября по апрель. Об этом свидетельствует надпись на каменном блоке в Преславе. В 1078 году куманы вместе с печенегами опустошили окрестности Адрианополя. Однако затем между двумя кочевыми народами возник конфликт, переросший в войну. В конечном счете, объединившись, куманы и ромеи разгромили печенегов в битве при Левунионе (1091 г.) и уничтожили печенежскую угрозу, нависшую над Балканами. В следующем, XII веке куманы периодически вторгались на болгарские земли, предпринимая грабительские кампании, которые, вопреки усилиям Византии, несли разруху и опустошение. Неоднократно куманов вытесняли и отбрасывали за Дунай, а плененных «скифов» насильно расселяли со статусом стратиотов близ Софии и Ниша. Отдельные группы куманов сами добровольно поселились в СевероВосточной Болгарии, в районах, ранее заселенных печенегами - около городов Плиска, Мадара и Преслав, что подтверждают найденные прямые материальные доказательства.

$$
\text { *** }
$$

Этническая картина в эпоху возрожденного Болгарского царства (1185-1396) продолжает носить постоянно динамично меняющийся характер. Куманский фактор присутствует прочно и осязаемо как результат не только союзных взаимоотношений болгарского правящего двора с задунайскими «скифами», но и двух новых миграционных волн: первая - в 1237 году, когда вновь пришедшие куманы, спасающиеся от монгольской угрозы, заселили Восточную Фракию, и вторая - весной 1241 г., когда переселенцами стали куманы-христиане Венгерского королевства. Именно они положили начало аристократическим династиям, которые в определенные периоды занимали болгарский престол - речь идет о родах Тертеров и Шишманов (Павлов, 1987, с. 634).

В конце XIII и в XIV веках к красочной этнической палитре Второго Болгарского царства добавились новые миграционные волны разнородного происхождения: золотоордынские татары, аланы-ясы, русины 
и другие. Так, нам известно присутствие монголо-татар на болгарской военной службе в XIV веке (Павлов, 1987). После распада Ногайского улуса из-за центробежных сил и междоусобиц значительная часть его населения переместилась на юг от Дуная и поселилась на северо-западе Болгарии (Илиев, 2015). В конце XIV века в Северо-Восточной Болгарии появились поселения татар под предводительством Актавы (Павлов, Владимиров, 2009 , c. 129).

Особенно интересно, но недостаточно изучено присутствие и роль аланов-ясов в истории средневековой Болгарии. Их появление на землях Нижнего Дуная тесно связано с серией куманских миграций, о которых уже шла речь. Из источников известно, что аланы входили в состав войска болгарского царя Калояна в самом начале XIII века. В византийских хрониках есть записи об аланах, входивших в состав Ногайского улуса, которые после его распада перешли на сторону Византии, а позднее, в 1306 году, часть их «вместе с женами и детьми» поселились на болгарских землях. Аланы-ясы входили в свиту Чака при его прибытии в Тырново и затем остались на болгарской службе. О более позднем этапе в летописях упоминается, что во времена правления Георгия II Тертера (1322-1323) управление Филиппополем было поручено аланскому корпусу в составе 1000 человек во главе с Итилем, Темиром и венгром Инасом. В Видинском царстве в 1365 году ясы сражались на стороне Ивана-Срацимира против венгерского короля. Очевидно, что аланское население было составным элементом средневековой болгарской народности не только в эпоху раннего Средневековья, но и в XIII-XIV веках. Это факт, который следует учитывать при изучении демографических процессов и миграционной активности на Балканах во времена зрелого и позднего Средневековья.

Анализ изложенного до сих пор подводит нас к логичному выводу, что этническая динамика на болгарских землях в период зрелого и позднего Средневековья была очень активной. Не исключено, что именно она детерминировала в определенной степени процессы сепаратизма, характерные для Второго Болгарского царства накануне османской экспансии.

$$
\text { *** }
$$

Материальные следы новоприбывших в XII-XIV веках на болгарские земли этнических групп хоть и немногочисленны, но представляют интерес для болгарской архе- ологической науки. Опубликовано несколько комплексно-обобщающих и конкретных исследований (Рашев, 1983; Йотов, Атанасов, 1998; Борисов, Шейлева, 2000; Дончева-Петкова, 2005; Борисов, 2006; Рашев, 2007; Валериев, 2015), правда, отсутствуют исчерпывающие научные разработки данного вопроса. В некоторой степени для этого есть объективные предпосылки: уже отмечалось, что новоприбывшие этносы занимали старые болгарские поселения, ассимилируя местную материальную культуру, принимая христианство и его погребальные обряды, и, как следствие, они быстро теряли свою изначальную, культуру (Рашев, 2007, с. 120-121). Такое, вновь сформированное население в византийских источниках получило название «миксоварвары».

В X-XI веках все еще можно проследить в чистом виде этноопределяющие черты погребального обряда поздних кочевников: для печенегов - это положение покойника головой на запад, для куманов - на восток. В XI-XII веках постепенно формируется единый этнический массив, в погребальных обрядах которого смешались черты традиций печенегов, торков и куманов, а также народностей, присоединившихся к ним по пути на запад. Новая синкретическая культура, которой присущ поздний номадский характер, зачастую не может быть этнически и конфессионально однозначно определена. Как справедливо подметила болгарский исследователь Л. Дончева-Петкова, болгарская наука не уделяла достаточного внимания некрополям XI века к югу от Дуная, все они были объявлены болгарскими, в основном из-за западной ориентации погребенных (Дончева-Петкова, 2002, с. 91). Эмблематичными погребальными памятниками, оставленными печенегами, являются два некрополя с более чем 600 могилами у села Одырци Добричской области (Дончева-Петкова, 2005). Во дворцовом центре Плиски обнаружены три поздних захоронения, одно из которых в кирпичной печи (Михайлова, 2003). Подобные захоронения были найдены и в других местах на территории первой столицы Болгарии (Антонова, Витлянов, 1985, с. 65; Димитров, 1996, с. 45; Балабанов, 2000, с. 93-95). Предполагается, что они принадлежат печенегам, населявшим эту местность в XI веке, о чем свидетельствуют византийские письменные источники. Над дворцом хана Крума и Тронным залом были исследованы 32 вкопанных жилища, в которых обитали кочевники. Сходство погребальных обычаев и материальной культуры пече- 
негов из Одырци и Плиски позволяет сделать вывод, что речь идет о представителях одного и того же рода или клана (Дончева-Петкова, 2003, с. 252).

Позднекочевническими являются и два захоронения могильника I, и три захоронения могильника III близ Мадары (Рашев, 2007, c. 123), вторичные захоронения у вбитых камней - «девташлари» рядом с Плиской (Рашев, 1992, с. 18), вторичные захоронения могильника римской эпохи у села Медникарово и могильника у села Ковачево Старозагорской области (Борисов, Шейлева, 2000, c. 248; Рашев, 2007, с. 124), захоронение № 45 могильника средневекового Созополя (Панайотова, 2015, с. 175). К данной категории памятников можно отнести и несколько захоронений некрополя у села Искра в районе города Пырвомай, два захоронения в средневековом некрополе у села Караново в районе Нова-Загора, захоронения в двух некрополях средневекового Пловдива, а также могилу воина близ села Златна-Ливада в районе Чирпана (Иванов, Иванов, 2005).

Присутствие поздних номадов южнее Дуная подтверждается и некоторыми специфическими находками, такими как глиняные котлы с внутренними «ушами», найденные в Плиске, Стырмене, селе Кривина (район Русе), селе Гиген (район Плевена), и горшки, украшенные гирляндами, из села Цар-Асен в районе Силистры (Димитров, 1975; Въжарова, 1981, с. 55; Рашев, 1983, с. 242). Найдены и описаны 16 так называемых «листовидных ажурных оберегов», которые считают продуктом материальной культуры печенегов. Найдены они были на северо-востоке Болгарии: в Варненской области, Шуменской области, Силистре и в крепости Скала в районе города Тервел (Йотов, Атанасов, 1998; Йотов, 2000). Также интерес представляет металлический наконечник украшения ремня конской сбруи, найденный у Плиски и с основанием отнесенный к печенежским (Атанасов, Крумова, 2005), как и оберег из Преслава (Бонев, 2014). Bce эти находки подтверждают известный, согласно письменным источникам, маршрут перемещений и мест оседлости печенегов.

Следы присутствия куманов на юге от Дуная также разнообразны (Владимиров, 2014). Особый интерес представляют две каменные бабы, найденные в районе Плиски, которые, несомненно, являются памятниками религиозных обрядов куманов. Захоронение куманина было обнаружено в могильнике XXV к западу от столицы Плиски: погребен- ный лежит головой на запад, вместе с конской кожей, рядом - меч и копье. Не так давно в ходе спасательных раскопок возле села Кермен в районе Сливена было обнаружено позднекочевническое захоронение с ориентацией усопшего головой на юг, и помещенного, вероятно, вместе с легким деревянным щитом. Датируется оно серединой или концом XI века, хотя не исключено, что ее можно отнести и к более поздней эпохе (Караилиев, 2019). С некоторыми куманскими нашествиями конца XI и XII века можно связать и найденные в районе города Шумен, хранящиеся сейчас в Государственном историческом музее меч и небольшой нож номадского типа (Инкова, 2016). Все эти материальные останки полностью соответствуют сведениям, имеющимся в письменных источниках и говорящих о районах обитания куманов и местах их поселений.

Особый интерес представляют археологические свидетельства еще одной болгарской диаспоры в составе поздних кочевников. Подтверждением такой миграции может служить некрополь Лимбар в Молдове, оставленный смешанным населением из местных и переселенцев, которое, по мнению исследователей, является потомком болгарских групп салтово-маяцкого населения (Великанова, 1975, с. 114-138). Возле южной крепостной стены Плиски были раскрыты две могилы, возможно, принадлежавшие донским болгарам - переселенцам в составе поздних номадов (Рашев, 1983, с. 250). Не исключено, что часть захоронений, ориентированных на север и расположенных преимущественно в западной части некрополя 3 крепости Красен в районе Панагюриште, также были оставлены такого рода населением (Григоров, 2010, c. 49).

Об археологических следах влияния Золотой Орды на болгарскую средневековую среду мы уже говорили в другой научной работе (Владимиров, 2018). Здесь лишь отметим, что памятники ювелирного искусства (зеркала, серьги в форме вопросительного знака), находки монет, образцы оружия и снаряжения золотоордынского происхождения все чаще встречаются на археологических объектах конца XIII и особенно XIV века, и их присутствие нельзя объяснить лишь торговлей, набегами или полученными дарами. Вот почему географическое и историческое их ситуирование позволяет объективно оценить масштабы феномена, названного в историографии «татарской гегемонией» в истории Второго Болгарского царства. 
***

Тема этнических изменений на болгарских землях в XI-XIV веках редко рассматривается через призму данных антропологического естества. К сожалению, антропологический анализ некрополей данного периода проводится редко. Они не находят отражения в историографических реконструкциях, а ряд значимых погребальных комплексов остается даже без последующего антропологического обследования. В имеющихся научных работах присутствует известная доля догматизма при подходе к эмпирическому материалу, необоснованно интерпретируемому в узких рамках трех архетипических составляющих средневековой болгарской народности - праболгар, славян и фракийцев.

В целом антропологи продолжают констатировать в изученных некрополях XI-XIV веков присутствие европеоидов с монголоидной примесью в той или иной степени. Эти монголоидные примеси, чаще всего доминирующие в женских краниологических сериях (Шумен, Ракитово, Караново, памятники региона «Марица-восток»), интерпретируются исследователями как «праболгарский субстрат», что в контексте рассматриваемого нами периода не звучит убедительно на фоне описанного ранее этнического разнообразия вследствие динамики развития диаспоры. Еще более дискуссионным является регистрация в данный период «фракийских элементов», которые, с некоторыми оговорками в отношении региона Родоп, трудно доказуемы даже во времена зарождения Дунайской Болгарии в конце VII века (Матанов, 2014, c. 48-53). Так, к «фракийцам» относят представителей средиземноморской и динарской рас, найденных в некрополях позднего Средневековья, упуская из виду тот факт, что, например, алано-сарматские группы тоже принадлежат к средиземноморской категории населения, а динарские черты характерны и для разнородного населения Малой Азии. Не вдаваясь в подробности, которым будет посвящено отдельное исследование, отметим лишь несколько показательных фактов антропологического естества, касающихся миграционных процессов на Балканах в XI-XIV веках.

Антропологический анализ обитателей Шуменской крепости в XII-XIV веках, т. е. там, где археологическим путем были обнаружены многочисленные следы золотоордынского характера (Владимиров, 2018, с. 36-42), указывает на следы населения с европеоидными характеристиками и со слабо выраженными монголоидными примесями. Среди черепов женской серии присутствует и искусственно деформированный - факт, который интерпретируется как «праболгарский элемент» (Минков, Боев, 1985). Отметим только, что подобный череп с искусственной деформацией был зарегистрирован и в захоронении XI века у села Кривина в районе Русе. Речь идет об европеоиде со слабо выраженными монголоидными примесями. Предполагается, что это был печенег (Боев, Минков, 1980), хотя и не исключено, что он мог быть дальним потомком сарматов. Христианизация болгар в IX веке положила конец данной языческой традиции, и вряд ли можно интерпретировать совершенное два века спустя как культурный рудимент более ранней эпохи.

В некрополе крепости «Боженишки Урвич» Ботевградской области обнаружены следы представителей уральской расы, которые антропологи вновь относят к «праболгарскому населению», хотя сам памятник датируется XII-XIV вв. (Боев, Кондова, Чолаков, 1979, с. 147). Для курганов-могильников, содержащих характерные для золотоордынской культуры серьги в виде знака вопроса (Луковит, Чиракман и Калиакра, Преслав, район села Мадара Шуменской области и села Янтра Горнооряховской области), антропология не допускает эвристичности в выводах, при этом следует отметить, что анализ некрополей у села Янтра даже не проводился.

Еще более показательны случаи с некрополями XII-XIV веков около города Перник и у села Прибой в районе Перника, где обнаружены следы населения уральского, байкальского и палеосибирского происхождения, которые никак не могут быть частью праболгарского компонента средневековой болгарской народности (Боев, Кондова, Чолаков, 1983). В некрополе крепости Перник был исследован скелет женщины с данными о наличии болезни «Кашина-Бека», которая, и это доказано, характерна для регионов Северного Китая, Маньчжурии и Северной Кореи (Горанов, Боев, Кондова, Чолаков, 1980). По-видимому, можем говорить о представителе поздних кочевников, которые, как известно из источников, заселили именно эти земли.

Из изложенного закономерно следует вывод о том, что антропологические анализы и заключения не должны ограничиваться только поиском фракийского, славянского и праболгарского субстрата в средневековой болгарской народности XI-XIV веков. Их необходимо в обязательном порядке контек- 
стуально сочетать со сведениями и данными историко-археологического естества во избежание архаизации и «лабораторного» ограничения научной интерпретации. Такой междисциплинарный подход позволит дополнить ценной информацией известные нам в настоящее время данные об этническом облике средневековых болгарских земель в XII-XIV веках. Несомненно, это перспективная задача, стоящая перед будущими исследователями-медиевистами.

\section{ЛИТЕРАТУРА}

Антонова В., Витлянов С. Плиска. Западна крепостна стена - сектор Север (археологически разкопки 1973-1975). // Плиска-Преслав. Т. 4 / Отг. ред. Д. Ангелов. София: Изд. БАН, 1985. С. 44-78.

Атанасов Г. Етнодемографски проблеми в Добруджа (X-XIV в.). // Исторически преглед. 1991. № 2. C. $78-82$.

Атанасов Г., Крумова Т. Нов паметник на печенежката металопластика от с. Стан, Новопазарско // Проф. д.и.н. Станчо Ваклинов и средновековната българска култура. / Ред. К. Попконстантинов, Б. Борисов. Велико Търново: Св. Св. Кирил и Методий, 2005. С. 248-253.

Балабанов T. Некропольт при Северната порта и източната крепостна стена на Плиска // ПлискаПреслав. Т. 8 / Отг. ред. Р. Рашев. Шумен: Антос, 2000. С. 93-102.

Боев П., Кондова Н., Чолаков С. Антропологично проучване на скелетите от некропола на крепостта «Боженишки Урвич» // Интердисциплинарни изследвания. T. III-IV / Отг. ред. Х. Тодорова. София: АИ-БАН, 1979. С. 139-148.

Боев П., Кондова Н., Чолаков С. Средновековният некропол. Антропологични данни. // Перник. Т. 2. / Ред. Д. Овчаров. София: Изд. БАН, 1983. С. 185-212.

Боев П., Минков Ц. Антропологично проучване на изкуствено деформиран череп, открит в с. Кривина, Русенско. // Интердисциплинарни изследвания. T. V-VI / Отг. ред. Х. Тодорова. София: АИ-БАН, 1980. C. $143-147$.

Бонев $C$. Единадесетият век върху руините на владетелската резиденция във Велики Преслав // Средновековният човек и неговият свят: сборник в чест на 70-та годишнина на проф. д.и.н. Казимир Попконстантинов / Отг. ред. Р. Костова. Велико Търново: Фабер, 2014. С. 469-473.

Борисов Б. Демографските промени в през XI-XII век в днешните български земи (археологически свидетелства) // Тангра. Сборник в чест на 70-годишнината на акад. Васил Гюзелев. / Ред. М. Каймакамова, Х. Темелски, И. Илиев, Л. Симеонова, Г. Николов. София: Св. Климент Охридски, 2006. C. 391-408.

Борисов Б., Шейлева Г. Археологически данни за късни номади на юг от Балкана // Плиска-Преслав, Т. 8. / Отг. ред. Р. Рашев. Шумен: Антос, 2000. С. 247-251.

Валериев Й. Българските земи и нашествията на късните номади в края на XI-XII в. Автореф. на дис. за присъждане на образователна и научна степен «доктор». София, 2015. 50 с.

Великанова М. Палеоантропология Прутско-Днестровского Междуречья. М.: Наука, 1975. 270 с.

Владимиров. Г. Материальные следы куманов в болгарских землях (конец XI - середина XIII в.): проблемы изучения // Поволжская археология. 2014. № 3(9). С. 242-255.

Владимиров Г. Серьги в виде знака вопроса из средневековой Болгарии (XIII-XIV вв.). Казань: Изд-во АН РТ, 2018. 128 с.

Въжарова Ж. Славяни и номади на територията на днешните български земи от края на VI-XI в. // Плиска-Преслав. Т. 3 / Ред. Д. Ангелов, Ж. Въжарова. София: Изд. БАН, 1981. С. 16-65.

Горанов П., Боев П., Кондова Н., Чолаков С. Палеопатологични данни за болестта на Кашин-Бек при средновековен скелет // Педиатрия. 1980. № 4. С. 389-394.

Григоров В. Крепостта Красен до Панагюрище. // Разкопки и проучвания. Т. 40. София: НАИМБАН, 2010. $352 \mathrm{c}$.

Гюзелев В. Очерци върху историята на Българския североизток и Черноморието (края на XII - началото на XV в.). София: Борина, 1995. 144 с.

Димитров Д. Номадска керамика в Североизточна България // Известия на Народния музей-Варна. 1975. № 11. С. 37-57.

Димитров Д. Прабългарите по Северното и Западното черноморие. Варна: Георги Бакалов, 1987. $304 \mathrm{c}$.

Димитров Я. Църква и некропол във Външния град на Плиска (края на X-XI в.) // Плиска-Преслав. Т. 7 / Отг. ред. Р. Рашев. Шумен: Славчо Николов и сие, 1996. С. 43-70. 
Дончева-Петкова Л. За етническата принадлежност на някои некрополи от XI в. // Криптохристиянство и религиозен синкретизъм. / Ред. Н. Дамянов, С. Димитров, Р. Попов. София: ЕИМ-БАН, 2002. C. 91-95

Дончева-Петкова Л. Плиска и печенезите // Плиска-Преслав, Т. 9. / Отг. ред. Р. Рашев. Шумен: Антос, 2003. С. 244-258.

Дончева-Петкова Л. Одърци. Т. 2 Некрополи от ХІ в. София: АИ «Марин Дринов», 2005. 472 с.

Иванов Р., Иванов Р. Погребални обреди на печенези и кумани по българските земи (XI-XIII в.). Пловдив: Изд. «Имеон», 2015. 188 с.

Илиев Н. Номади в историята на средновековните северозападни български земи. // Епохи. 2015. № 2. С. 483-488.

Инкова М. Средновековни сабя и ножче от експозицията на Националния исторически музей София. // Известия на Националния археологически институт. In honorem professoris Stanislav Stanilov. XLIII / Отг. ред. А. Божкова. София: НАИМ-БАН, 2016. С. 431-460.

Йотов В. О материальной культуре печенегов к югу от Дуная - листовидные ажурные амулеты XI в. // Stratum plus. 2000. № 5. C. 209-212.

Йотов В., Атанасов Г. Скала: крепост от X-XI век до с. Кладенци, Тервелско. София: Pensoft, 1998. $346 \mathrm{c}$.

Караилиев П. Късно номадско погребение край град Кермен. // Преслав, Т. 8 / Отг. ред. С. Бонев. Велико Търново: Изд. «Фабер», 2019. С. 474-483.

Матанов X. В търсене на средновековното време: неравният път на българите (VII-XV в.). София: ИК «Гутенберг». 2014. 516 с.

Минков Ц., Боев П. Антропологично проучване на средновековни черепи от Шуменската крепост // Годишник на Софийския университет - Биологически факултет. Т. 75. Кн. 1 Зоология / Отг. ред. С. Стефанов. София: УИ «Св. Климент Охридски», 1985. С. 99-107.

Михайлова Т. Къснономадски гробове в дворцовия център на Плиска // Плиска-Преслав, Т. 9. / Отг. ред. Р. Рашев. Шумен: Изд. «Антос», 2003. С. 259-266.

Павлов, П. Монголотатари на българска военна служба през XIV в. // Военноисторически сборник. 1987. № 2. C. 112-120.

Павлов П. По въпроса за заселванията на кумани в България през XIII в. // Втори международен конгрес по българистика. Доклади. Т. 6 / Отг. ред. Х. Христов. София: Изд. БАН, 1987. С. 629-637.

Павлов П. Бунтари и авантюристи в средновековна България. Велико Търново: Изд. «Абагар». 2000. $200 \mathrm{c}$.

Павлов, П. Владимиров, Г. Златната орда и българите. София: Военно издателство, 2009. 176 с.

Панайотова $K$. Средновековни обекти на територията на античния некропол на Аполония в м. Калфата/Буджака - Созопол // Известия на Народния музей - Бургас. Т. 5 / Отг. ред. М. Николов. Бургас: РИМ-Бургас, 2015. С. 173-182.

Рашев Р. Късни номади в плисковското поле. // Преслав, Т. 3 / Отг. ред. Т. Тотев. Варна: Георги Бакалов, 1983. С. 242-252.

Рашев Р. Девташларите - мегалитни паметници на българската езическа култура. // Плиска-Преслав, Т. 5. /Отг. ред. Р. Рашев. Шумен: Изд. «Хермес и хермес», 1992. С. 5-31.

Рашев Р. Куманите на юг от Дунав по археологически данни. // 800 години от битката при Одрин. / Ред. Н. Неделчев. Шумен: Изд. «Аксиос», 2007. С. 120-130.

Стоянов В. Куманите в българската история (XI-XIV в.). // Исторически преглед. 2005. № 5-6. C. $3-25$.

Тъпкова-Заимова В. Долни Дунав - гранична зона на византийския Запад. София: Изд. БАН, 1976. $188 \mathrm{c}$.

\section{Информация об авторе:}

Владимиров Георги Владимиров, доктор по истории, магистр по культурологии, главный эксперт, Министерство культуры Республики Болгария (г. София, Болгария); vladimirovkult@yahoo.com

\section{REFERENCES}

Antonova, V., Vitlyanov, S. 1985. In Angelov, D. (ed.). Pliska-Preslav (Pliska-Preslav) 4. Sofiia: Bulgarian Academy of Sciences Publ., 44-78 (in Bulgarian).

Atanasov, G. 1991. Istoricheski pregled (Historical Review). 2. 78-82 (in Bulgarian). 
Atanasov, G., Krumova, T. 2005. In Popkonstantinov, K., Borisov, B. (ed.). Prof. d.i.n. Stancho Vaklinov $i$ srednovekovnata blgarska kultura (Professor, Doctor of Historical Sciences Stancho Vaklinov and the Medieval Bolgar Culture). Veliko Tarnovo: "Kiril i Metodii" Publ., 248-253 (in Bulgarian).

Balabanov, T. 2000. In Rashev, R. (ed.). Pliska-Preslav (Pliska-Preslav) 8. Shumen: “Antos” Publ., 93-102 (in Bulgarian).

Boev, P., Kondova, N., Cholakov, S. 1979. In Todorova, Kh. (ed.). Interdistsiplinarni izsledvaniia (Interdisciplinary Studies) III-IV. Sofiia: Bulgarian Academy of Sciences, 139-148 (in Bulgarian).

Boev, P., Kondova, N., Cholakov, S. 1983. In Ovcharov, D. (ed.). Pernik (Pernik) 2. Sofiia: Bulgarian Academy of Sciences, 185-212 (in Bulgarian).

Boev, P., Minkov, Ts. 1980. In Todorova, Kh. (ed.). Interdistsiplinarni izsledvaniia (Interdisciplinary Studies) V-VI. Sofiia: Bulgarian Academy of Sciences, 143-147 (in Bulgarian).

Boev, P. 2014. In Kostova, R. (ed.). Srednovekovniiat chovek i negoviiat sviat: sbornik $v$ chest na 70-ta godishnina na prof. d.i.n. Kazimir Popkonstantinov (The Medieval Man and His World: Collection in Commemoration of the 70th Anniversary of Professor, Doctor of Historical Sciences Kazimir Popkonstantinov) Veliko Tarnovo: "Faber" Publ., 469-473 (in Bulgarian).

Borisov, B. 2006. In Kaimakamova, Temelski, Kh., Iliev, I., Simeonova, L., Nikolov, G. (eds.). Tangra. Sbornik v chest na 70-godishninata na akad. Vasil Giuzelev (Tengri. Collection of Commemoration of the 70th Anniversary of Academician Vasil Gyuzelev) Sofia: "Sv. Kliment Okhridski" Publ., 391-408 (in Bulgarian).

Borisov, B., Sheileva, G. 2000. In Rashev, R. (ed.). Pliska-Preslav (Pliska-Preslav) 8. Shumen: "Antos" Publ., 247-251 (in Bulgarian).

Valeriev, I. 2015. Blgarskite zemi i nashestviiata na ksnite nomadi v kraia na XI-XII v. (Bolgar Lands and the Invasions of Late Nomads in the Late $11^{\text {th }}-12^{\text {th }} \mathrm{cc}$.) Thesis of Diss. of Doctor of Historical Sciences. Sofia (in Bulgarian).

Velikanova, M. 1975. Paleoantropologiia Prutsko-Dnestrovskogo Mezhdurech'ia (Palaeoanthropology of the Prut-Dniester Interfluve). Moscow: "Nauka" Publ. (in Russian).

Vladimirov, G. 2014. In Povolzhskaya arkheologiya (Volga River Region Archaeology) 9 (3), 242-255 (in Russian).

Vladimirov, G. 2018. Ser'gi v vide znaka voprosa iz srednevekovoi Bolgarii (XIII-XIVvv.) (Earrings in the Form of a Question Mark from Bolgaria (13 ${ }^{\text {th }}-14^{\text {th }} \mathrm{cc}$.)).Kazan: Tatarstan Academy of Sciences (in Russian).

Vzharova, Zh. 1981. In Angelov, D., Vzharova, Zh. (eds.). Pliska-Preslav (Pliska-Preslav) 3. Sofiia: Bulgarian Academy of Sciences Publ., 16-65 (in Bulgarian).

Goranov, P., Boev, P., Kondova, N., Cholakov, S. 1980. In Pediatria (Pediatrics) 4, 389-394 (in Bulgarian).

Grigorov, V. 2010. Krepostta Krasen do Panagiurishche (Krasen Fortress near Panagyurishte). Series: Razkopki i prouchvaniia (Excavations and investigations) 10. Sofia: Bulgarian Academy of Sciences (in Bulgarian).

Giuzelev, V. 1995. Ochertsi vrkhu istoriiata na Blgarskiia severoiztok i Chernomorieto (kraja na XII nachaloto na XV v.). (Essays on the History of the Bolgar North-East and the Black Sea Coast (Late 12 $2^{\text {th }}-$ early 15 ${ }^{\text {th }}$ cc.).). Sofia: "Borina" Publ. (in Bulgarian).

Dimitrov, D. 1975. In Izvestiia na Narodniia muzei-Varna (Bulletin of the National Museum - Varna) 11, 37-57. (in Bulgarian).

Dimitrov, D. 1987. Prablgarite po Severnoto i Zapadnoto chernomori (Proto-Bolgars on the North and West Black Sea Coasts). Varna: "Georgi Bakalov" Publ. (in Bulgarian).

Dimitrov, Ya. 1996. In Rashev, R. (ed.). Pliska-Preslav (Pliska-Preslav) 7. Shumen, 43-70 (in Bulgarian).

Doncheva-Petkova, L. 2002. In Damianov, N., Dimitrov, S., Popov, R. (eds.). Kriptohristiianstvo $i$ religiozen sinkretizm (Crypto-Christianity and Religious Syncretism). Sofia: Bulgarian Academy of Sciences Publ., 91-95 (in Bulgarian).

Doncheva-Petkova, L. 2003. In Rashev, R. (ed.). Pliska-Preslav (Pliska-Preslav) 9. Shumen: ":Antos" Publ., 244-258 (in Bulgarian).

Doncheva-Petkova, L. 2005. Odrtsi. Nekropoli ot XI v. (Odartsi. Necropolis of the $11^{\text {th }}$ c.) 2. Sofia: "Marin Drinov" Publ. (in Bulgarian).

Ivanov, R., Ivanov, R. 2015. Pogrebalni obredi na pechenezi i kumani po blgarskite zemi (XI-XIII v.).). (Burial Rites of the Pechenegs and Cumans in Bolgar Lands (11 th $13^{\text {th }} c c$.)). Plodiv: "Imeon" (in Bulgarian).

Iliev, N. 2015. In Epokhi (Epochs) 2, 483-488 (in Bulgarian).

Inkova, M. 2016. In Izvestiia na Nacionalniia arkheologicheski institute (Reports of the National Archaeological Institute). XLIII, 431-460 (in Bulgarian). 
Yotov, V. 2000. In Stratum Plus. 5, 209-212 (in Russian).

Yotov, V., Atanasov, G. 1998. Skala: krepost ot X-XI vek do s. Kladenci, Tervelsko (Skala: $10^{\text {th }}-11^{\text {th }}$ Century Fortress near Kladentsi Village, Tervel). Sofia: "Pensoft" Publ. (in Bulgarian).

Karailiev, P. 2019. In Bonev, S. (ed.). Preslav (Preslav) 8. Veliko Tarnovo: "Faber" Publ., 474-483 (in Bulgarian).

Matanov, Kh. 2014. V trsene na srednovekovnoto vreme: neravniiat pt na blgarite (VII-XV v.) (In Search of the Middle Ages: the Hard Road of the Bolgars ( $7^{\text {th }}-15^{\text {th }} c c$.)). Sofia: "Gutenberg" Publ. (in Bulgarian).

Minkov, Ts., Boev, P. 1985. In Stefanov, S. (ed.). Godishnik na Sofijskija universitet (Yearbook of Sofia University) 75 (1). Sofia: “Sv. Kliment Okhridski” Publ., 391-408 (in Bulgarian).

Mikhailova, T. 2003. In Rashev, R. (ed.). Pliska-Preslav (Pliska-Preslav) 9. Shumen: "Antos" Publ., 259-266 (in Bulgarian).

Pavlov, P. 1987. In Voennoistoricheski sbornik (Military History Collection) 2, 112-120 (in Bulgarian).

Pavlov, P. 1987. In Khristov, Kh. (ed.). Vtori mezhdunaroden congress po blgaristika (Second International Congress on Bolgar Studies) 6. Sofia: Bulgarian Academy of Sciences, 629-637 (in Bulgarian).

Pavlov, P. 2000. Buntari i avantiuristi v srednovekovna Blgariia (Rebels and Adventurers in Medieval Bolgaria). Veliko Tarnovo: “Abagar" Publ. (in Bulgarian).

Pavlov, P., Vladimirov, G. 2009. Zlatnata orda i blgarite (The Golden Horde and the Bolgars). Sofia: "Voenno izdatelstvo" Publ. (in Bulgarian).

Panaiotova, K. 2015. In Nikolov, M. (ed.). In Izvestiia na Narodiia muzei-Burgas (Bulletin of the National Museum - Burgas) 5. Burgas: "PIM-Burgas" Publ., 173-182 (in Bulgarian).

Rashev, R. 1983. In Totev, T. (ed.). Preslav (Preslav) 3. Varna: "Georgi Bakalov" Publ., 242-252 (in Bulgarian).

Rashev, R. 1992. In Rashev, R. (ed.). Pliska-Preslav (Pliska-Preslav) 9. Shumen: "Hermes i hermes" Publ., 5-31 (in Bulgarian).

Rashev, R. 2007. In Nedelchev, N. (ed.). 800 godini ot bitkata pri Odrin (The $800^{\text {th }}$ Anniversary of the Battle of Edirne). Shumen: "Aksios" Publ., 120-130 (in Bulgarian).

Stoyanov, V. 2005. Istoricheski pregled (Historical Review) (5-6). 3-25 (in Bulgarian).

Tpkova-Zaimova, V. 1976. Dolni Dunav - granichna zona na vizantiiskiia Zapad (Lower Danube - the Border Area of the Byzantine West). Sofia: Bulgarian Academy of Sciences (in Bulgarian).

\section{About the Author:}

Vladimirov Georgi V. Ph.D. (History), Master of Cultural Studies, Chief Expert, Ministry of Culture of Republic Bulgaria. bul. "Al.Stambliiski", 17, Sofia, 1040, Bulgaria; vladimirovkult@yahoo.com 